\title{
Eosinophils in HIV Patients Co-Infected by HTLV-1 and/or Strongyloïdes stercoralis: Protective or Harmful Depending on HIV Infection Stage
}

Yves Plumelle*, Vanessa Cornely, Alice Eischen, Odile Bera, Nicole Desbois, Andre Cabie and Andre Edouard

University Hospital of Martinique, Fort de France, Martinique, France

\begin{abstract}
Polymorphonuclear eosinophils are source of chemokines such as RANTES and IL-16. These chemokines suppress the in vitro viral replication of HIV primary strains and so could contribute to the resistance of infection in HIV seronegative patients despite their belonging to risk groups. Hypothesis considering eosinophilia as a protective factor against HIV infection by overexposing RANTES was tested. Therefore we studied the impact of co-infections of human T lymphotropic virus-1 (HTLV-1) and Strongyloïdes stercoralis (Ss), infectious agents potentially eosinophylogenic, on the eosinophilic reaction in HIV patients and on the patients' survival. From 1983 to 1996, 445 HIV infected patients had a follow-up for at least one year of whom $52 \%$ developed AIDS, $13 \%$ presented with HTLV-1, $15 \%$ with Ss coinfection and $23 \%$ showed eosinophilia superior to $1.10 \times 9 / \mathrm{L}$. Our results indicate that eosinophilia provoked by Ss was not altered by HTLV-1. Furthermore the reactive ability of eosinophils was not affected by the drastic decrease of CD4-T observed in HIV patients. HIV patients co-infected by HTLV-1 presented higher amounts of CD4-T as compared to patients only infected by HIV, but no effect on CD8-T and eosinophils amount was observed. The median age superior in HTLV-1/Ss co-infected HIV patients suggested an asymptomatic period lengthened because of later diagnostic and a protective effect of these co-infections. However patients' survival in AIDS phase was neither changed by eosinophilia nor by the HTLV-1 and Ss co-infections.
\end{abstract}

Keywords: HIV; HTLV-1; Strongyloïdes stercoralis; Eosinophilia; Retroviral interactions

\section{Introduction}

Peripheral eosinophils represent less than $1 \%$ of total eosinophils, which are mainly tissular cells. As compared to lymphocytes $\left(10^{12}\right)$ of which $2 \%$ are circulating cells, the total population of eosinophils $\left(10^{10}\right)$ is one hundred times lower, but in the progression of HIV infection they become relatively more important.

The relative resistance to the HIV infection of patients belonging to risk groups seems associated to the activities of three $\beta$-chemokines CC, namely RANTES, MIP-1 $\alpha$, MIP-1 $\beta$ [1]. These chemokines and IL-16 suppress the in vitro viral replication of primary strains of HIV [2-4]. Furthermore they block CCR5, the second receptor of primary non-syncytium-inducing or macrophage (M)-tropic HIV expressed at the surface of CD4-T cells and monocytes. Among the chemokines RANTES represents the one showing the most important affinity to CCR5 [4]. In vitro activated eosinophils are source of chemoattractants such as RANTES and IL-16 [5-7].

In HIV patients, various co-infections are observed and according to the secreted cytokines, they affect the HIV infection in a favorable or unfavorable manner [8]. In Martinique, HIV-infected patients may be co-infected by HTLV-1 and Strongyloïdes stercoralis (Ss), two endemic infectious agents having an inductive capacity of eosinophilia [9-12]. Here we propose the reactive ability of eosinophils in HIV-infected patients as a relative protective factor against HIV through a high expression of ligand RANTES in eosinophils [5-7]. In order to study this hypothesis, we investigate the role of the co-infections of HTLV-1 and/or Ss on the eosinophilic reaction and the impact of eosinophilia on the survival of HIV-infected patients.

\section{Methods}

The definition of eosinophilia retained in this study corresponds to a number of circulating eosinophils equal or superior to $1.10^{9} / \mathrm{L}$. Eosinophils were considered on the one hand by the presence $\left(>1.10^{9} / \mathrm{L}\right)$ or absence $\left(<1.10^{9} / \mathrm{L}\right)$ of eosinophilia and on the other hand by the maximal amount observed during the evolution of HIV infection. Analysis of eosinophilia was realized in terms of the stage of the disease, either at the asymptomatic or the AIDS stage. The presence of Ss was determined by direct detection of rhabditiform larvae in fresh stool samples concentrated by the Baerman funnel technique and/or by direct detection of larvae in bronchoalveolar lavage fluid and gastric fluid. Serum specimens were screened for antibodies to HTLV-1 with an enzyme-linked immunosorbent assay. Positive results were confirmed by Western blot analysis. Subsets of CD4-T and CD8-T cells were analyzed by flow cytometry (FACStar or FACScalibur, Becton Dickinson). Indicated values of CD4-T and CD8-T correspond at the moment when a maximal number of eosinophils was observed at any stage of the disease. Rates of HTLV-1 co-infection and Ss co-infection and eosinophilia were compared for different CD4-T counts either inferior to $0.2 .10^{9} / \mathrm{L}$, between $0.2 .10^{\%} / \mathrm{L}$ and $0.5 .10^{9} / \mathrm{L}$ or superior to $0.5 .10^{9} / \mathrm{L}$.

\section{Patients}

From January 1,1983 to March 30,1996, 815 HIV-seropositive subjects were identified in Martinique and followed up at the University Hospital of Fort de France. Of them 378 (46\%) developed AIDS. During study period, none patient was treated by antiproteases known to alter the expression of RANTES $[13,14]$. To analyse the evolution of eosinophils and lymphocytes rates, only patients with a minimal follow-up of one year were included in the study. So, patients were

*Corresponding author: Yves Plumelle, University hospital of Martinique, Fort de France, Martinique, France, Tel: 0696209632; E-mail: yvesplumelle@yahoo.com

Received June 23, 2015; Accepted October 10, 2015; Published October 15, 2015

Citation: Plumelle Y, Cornely V, Eischen A, Bera O, Desbois N, et al. (2015) Eosinophils in HIV Patients Co-Infected by HTLV-1 and/or Strongyloïdes stercoralis: Protective or Harmful Depending on HIV Infection Stage. J AIDS Clin Res 6: 507. doi:10.4172/2155-6113.1000507

Copyright: (c) 2015 Plumelle $\mathrm{Y}$, et al. This is an open-access article distributed under the terms of the Creative Commons Attribution License, which permits unrestricted use, distribution, and reproduction in any medium, provided the original author and source are credited. 
investigated by a monthly lymphocyte and eosinophils blood count and by subsets of CD4-T and CD8-T cells. The cohort of patients were also tested for HTLV-1 and Ss infection. Hence HIV-patients involved in this study were separated into four groups: 1) patients only infected by HIV, 2) patients co-infected by HTLV-1, 3) patients co-infected by Ss, 4) patients co-infected by both HTLV-1 and Ss. The groups of patients were described by the following main characteristics: sex, prevalence of HTLV-1 and Ss, eosinophilia (presence or absence) and the correspondent numbers of CD4-T as well as CD8-T, the incidence of AIDS, patients' age at the moment of HIV infection diagnosis, the age of progression to AIDS, and age of maximal amount of eosinophils and of death.

\section{Statistical analysis}

Patients' characteristics: HTLV-1 infection, Ss infection, biological characteristics and the progression to AIDS were studied in terms of age and sex using univariate analysis. We used Chi-square test, ShapiroWilk test to verify normal distribution for the quantitative parameters and non-parametric Kruskall-Wallis test to inter-group comparison. Patients in whom Ss infection was not evaluated were excluded from analysis. The number of cases included $(\mathrm{N})$ varied as a result of missing values.

Longitudinal analysis: The study was applied to a cohort of patients having a minimal follow-up of one year between 1983 and 1996. Patients' age was taken into account for three irreversible events: 1) age of HIV infection diagnosis, 2) progression to AIDS, 3) death at any clinical stage of the disease. Ages and intervals between the different events are expressed in years. Survival is defined as the time in years from the known year of either HIV diagnosis, entrance in AIDS stage (CD4-T count $<0.2 .10^{9} / \mathrm{L}$ ), or maximal amount of eosinophils, until the occurrence of death. The influence of explanatory parameters such as sex, HTLV-1 infection, Ss infection and eosinophilia was investigated. Survival analysis was analyzed with actuarial method using March 30, 1996, as the study endpoint. The log-rank test was applied in order to compare the groups and to assure that during the follow-up there was no crossing-over of the curves obtained by the actuarial method. The Cox proportional hazards model was applied to appreciate the associated risk of the explanatory variables and the occurrence of each irreversible event.

Multivariate analysis: A model of logistic regression was used to study the influence of HTLV-1 and Ss on eosinophilia. First, univariate models were applied to evaluate the crude oddsratios of the explanatory parameters and their 95\% confidence intervals. Furthermore for the multivariate analysis only parameters significantly associated to eosinophilia were selected by using a limit inferior or equal to 25 percent. Finally interactions between the different parameters and potential confounders such sex were analyzed. Results are first presented for the whole cohort of patients, then for each group of patients either at the AIDS stage or the asymptomatic stage and finally for each CD4-T amount either inferior to $0.2 .10^{9} / \mathrm{L}$, between $0.2 .10^{9} / \mathrm{L}$ and $0.5 .10^{9} / \mathrm{L}$ or superior to $0.5 .10^{9} / \mathrm{L}$. Statistical significance was obtained by a p-value inferior to 0.05 . Statistical analyses were performed with statistical software STATA 7.0 (StataCorp, College Station, TX).

\section{Results}

During the period of study 445 patients were selected on the basis of a minimal follow-up of one year. Sex ratio was $2.3(310 \mathrm{M} / 135 \mathrm{~F})$. Two hundred and thirty one patient (51.9\%) progressed to AIDS, 181 (40.7\%) died and 27 patients (6.1\%) were lost to follow-up. Fifty-eight patients (13\%) were co-infected by HTLV-1 and 55 patients (14.9\%) of 368 patients tested were co-infected by Ss. One hundred and four patients $(23.4 \%)$ showed eosinophilia superior to $1.10^{9 /} \mathrm{L}$. The median age of HIV infection diagnosis, progression to AIDS, maximal amount of eosinophils and death were respectively of $35,40,38,41$ years. As the continuous variables did not follow the normal distribution, biological characteristics and the prevalence of infections were expressed as median values and percentages. All the parameters, i.e. CD4-T cells counts, eosinophilia, prevalence of HTLV-1 infection, Ss infection and the proportion of patients at the AIDS stage, except the amount of CD8-T and the percentage of death, showed a significant difference as analyzed in terms of sex (Table 1). Therefore, results are presented according to sex. The prevalence of Ss infection was significantly higher in patients infected by HTLV-1 as compared to non-infected patients (14/44 versus $\left.41 / 324, \mathrm{p}=10^{-3}\right)$.

The median age of HIV diagnosis and progression to AIDS and the median age of maximal amount of eosinophils were lower in patients who were not infected by HTLV-1 as compared to the other groups. These findings were independent of the clinical situation and of sex and they were observed despite the variable number of patients. Otherwise the median age of diagnosis time and progression to AIDS was higher in patients only infected by HTLV-1 as compared to patients only infected by Ss. The same difference was noted at the AIDS stage of disease (Table 2a-2c).

\section{Correlation between HTLV-1 infection, Ss infection and amounts of CD4-T, CD8-T and eosinophils}

Significantly higher values of CD4-T cells were observed in patients (whole cohort) without eosinophilia and also in patients co-infected by HTLV-1 or Ss as compared to those not co-infected. In opposition no significant difference could be observed concerning CD8-T cells under any condition (Table 3a). At the AIDS stage only HTLV-1 and Ss infections were associated with higher values of CD4-T; the amounts of CD8-T cells did not manifest any significant difference (Table 3b). At the asymptomatic stage, only Ss infection was associated with higher values of CD4-T (Table 3c). Classification of patients by the amount of CD4-T cells either inferior to $0.2 .10^{9} / \mathrm{L}$, between $0.2 .10^{\%} / \mathrm{L}$ and $0.5 .10^{9} / \mathrm{L}$ or superior to $0.5 .10^{9} / \mathrm{L}$ revealed that the HTLV-1 infection demonstrated a significantly higher number of patients with CD4-T

\begin{tabular}{|c|c|c|c|}
\hline Variables & $\begin{array}{c}\text { Male } \\
(N=310)\end{array}$ & $\begin{array}{c}\text { Female } \\
(\mathrm{N}=135)\end{array}$ & p-value \\
\hline CD4 (median) x 10\%/L & 0.128 & 0.211 & 0.0012 \\
\hline CD8 ((median) x 109/L & 0.762 & 0.695 & NS \\
\hline $\begin{array}{l}\text { Maximal amount of } \\
\text { Eosinophils* (median) } \times 10^{9} / \mathrm{L}\end{array}$ & 0.628 & 0.284 & $10^{-4}$ \\
\hline Variables & $\mathrm{N}(\%)$ & $N(\%)$ & \\
\hline Eosinophilia (>1.10\%/L) & $90(29)$ & $14(10.4)$ & $10^{-4}$ \\
\hline HTLV-1+ & $32(10.3)$ & $26(19.3)$ & 0.013 \\
\hline Ss+ ** & $48(18.3)$ & 7 (6.7). & $6.10^{-3}$ \\
\hline AIDS & $171(55.2)$ & $60(44.4)$ & 0.038 \\
\hline Death & $134(43.2)$ & $47(34.8)$ & NS \\
\hline
\end{tabular}

* Observed during the evolution of HIV infection

Ss: Strongyloïdes stercoralis, N: number of patients, NS=no significant, critical level: $p<0.05$

** Patients in whom the Ss infection was not evaluated were excluded (male:262 female: 135 ).

AIDS stage is defined by CD4-T count $<0.2 .10^{9} / \mathrm{L}$.

Table 1: Comparison of features of HIV patients, according to sex, diagnosed between 1983 and 1996 with a follow-up > one year (whole cohort) (Kruskall-Wallis test or Chi2 test for \%) 
Citation: Plumelle Y, Cornely V, Eischen A, Bera O, Desbois N, et al. (2015) Eosinophils in HIV Patients Co-Infected by HTLV-1 and/or Strongyloïdes stercoralis: Protective or Harmful Depending on HIV Infection Stage. J AIDS Clin Res 6: 507. doi:10.4172/2155-6113.1000507

Page 3 of 7

cells superior to $0.5 \cdot 10^{9} / \mathrm{L}$ (Table 4 ). The proportion of patients with eosinophilia was higher in the group of patients who demonstrated a CD4-T count inferior to $0.2 .10^{\%} / \mathrm{L}$ as compared to the other groups (Table 4).

\begin{tabular}{|c|c|c|c|c|c|c|}
\hline $\begin{array}{l}\text { Group of patients } \\
\text {-whole cohort* }\end{array}$ & $\mathbf{N}$ & $\begin{array}{c}\text { Age of HIV } \\
\text { diagnosis } \\
{[x, y, z]^{\star *}}\end{array}$ & $\mathbf{N}$ & $\begin{array}{c}\text { Age of AIDS } \\
\text { stage } \\
{[x, y, z]^{\star *}}\end{array}$ & $\mathbf{N}$ & $\begin{array}{l}\text { Age of } \\
\text { death }\end{array}$ \\
\hline HTLV- Ss- & 283 & {$[26,33,43]$} & 169 & {$[30,37,45]$} & 131 & {$[32,39,50]$} \\
\hline HTLV+ Ss- & 30 & {$[42,52,61]$} & 16 & {$[45,53,63]$} & 10 & {$[46,57,65]$} \\
\hline HTLV-Ss+ & 41 & {$[32,38,47]$} & 29 & {$[35,41,49]$} & 20 & {$[42,43,57]$} \\
\hline \multirow[t]{2}{*}{ HTLV+Ss+ } & 14 & {$[38,48,55]$} & 10 & {$[38,48,55]$} & 8 & {$[42,55,57]$} \\
\hline & & $p=0,0001$ & & $p=0,0001$ & & $p=0,0061$ \\
\hline \multicolumn{7}{|l|}{ Male } \\
\hline HTLV-Ss- & 203 & {$[27,34,43]$} & 123 & {$[31,38,45]$} & 96 & {$[33,39,49]$} \\
\hline HTLV+ Ss- & 13 & {$[47,51,57]$} & 8 & {$[49,53,65]$} & 4 & {$[40,49,59]$} \\
\hline HTLV-Ss+ & 36 & {$[31,36,45]$} & 25 & {$[35,40,48]$} & 17 & {$[37,43,50]$} \\
\hline \multirow[t]{2}{*}{ HTLV+Ss+ } & 12 & {$[35,43,54]$} & 9 & {$[38,44,55]$} & 7 & {$[41,54,57]$} \\
\hline & & $p=0.001$ & & $p=0.0043$ & & NS \\
\hline \multicolumn{7}{|l|}{ Female } \\
\hline HTLV- Ss- & 80 & {$[25,30,42]$} & 46 & {$[29,34,45]$} & 35 & {$[30,37,51]$} \\
\hline HTLV+ Ss- & 17 & {$[40,55,61]$} & 8 & {$[42,54,63]$} & 6 & {$[47,63,66]$} \\
\hline HTLV-Ss+ & 5 & {$[44,47,54]$} & 4 & {$[42,48,56]$} & 3 & {$[42,46,55]$} \\
\hline \multirow[t]{2}{*}{ HTLV+Ss+ } & 2 & 52,55 & 1 & 55 & 1 & \\
\hline & & $p=5.10^{-4}$ & & $p=0.03$ & & $p=0.05$ \\
\hline
\end{tabular}

${ }^{*}$ Patients in whom the Ss infection was not evaluated were excluded

${ }^{* *} \mathrm{x}, \mathrm{y}, \mathrm{z}$ : Percentile [25, 50, 75]

Ss: Strongyloïdes stercoralis

AIDS stage is defined by CD4-T count $<0.2 .10^{\%} / \mathrm{L}$

$\mathrm{N}$ : number of patients, NS: no significant, critical level: $p<0.05$

Table 2a: Age of HIV patients at the moment of three irreversible events (HIV diagnosis, AIDS stage, death) in the four groups in whole cohort ${ }^{\star}$ (Univariate analysis).

\begin{tabular}{|c|c|c|c|c|c|c|}
\hline $\begin{array}{l}\text { Group of patients } \\
\text { AIDS* }\end{array}$ & $\mathbf{N}$ & $\begin{array}{c}\text { Age of HIV } \\
\text { diagnosis } \\
{[x, y, z]^{\star *}}\end{array}$ & $\mathbf{N}$ & $\begin{array}{c}\text { Age of AIDS } \\
\text { stage } \\
{[x, y, z]^{* *}}\end{array}$ & $\mathbf{N}$ & $\begin{array}{c}\text { Age of death } \\
{[x, y, z]^{* *}}\end{array}$ \\
\hline HTLV-Ss- & 169 & {$[26,34,43]$} & 169 & {$[30,37,45]$} & 115 & {$[31,38,47]$} \\
\hline HTLV+ Ss- & 16 & {$[41,52,61]$} & 16 & {$[45,53,63]$} & 10 & {$[46,57,65]$} \\
\hline HTLV-Ss+ & 29 & {$[32,37,47]$} & 29 & {$[35,41,49]$} & 18 & {$[37,43,56]$} \\
\hline \multirow[t]{2}{*}{ HTLV+Ss+ } & 10 & {$[38,47,55]$} & 10 & {$[38,48,55]$} & 8 & {$[42,55,57]$} \\
\hline & & $p=0,0002$ & & $p=0,0001$ & & $p=0,003$ \\
\hline \multicolumn{7}{|l|}{ Male } \\
\hline HTLV- Ss- & 123 & {$[27,35,43]$} & 123 & {$[31,38,45]$} & 84 & {$[32,39,61]$} \\
\hline HTLV+ Ss- & 8 & {$[48,52,64]$} & 8 & {$[49,53,65]$} & 4 & {$[40,49,59]$} \\
\hline HTLV-Ss+ & 25 & {$[32,35,46]$} & 25 & {$[35,40,48]$} & 16 & {$[37,43,51]$} \\
\hline \multirow[t]{2}{*}{ HTLV+Ss+ } & 9 & {$[38,42,55]$} & 9 & {$[38,44,55]$} & 7 & {$[41,54,57]$} \\
\hline & & $P=0.01$ & & $P=0.0043$ & & NS \\
\hline \multicolumn{7}{|l|}{ Female } \\
\hline HTLV- Ss- & 46 & {$[26,29,42]$} & 46 & {$[29,34,45]$} & 31 & {$[30,37,51]$} \\
\hline HTLV+ Ss- & 8 & {$[39,52,61]$} & 8 & {$[42,54,63]$} & 6 & {$[47,63,66]$} \\
\hline HTLV-Ss+ & 4 & {$[40,46,51]$} & 4 & {$[42,48,56]$} & 2 & 42,46 \\
\hline \multirow[t]{2}{*}{ HTLV+Ss+ } & 1 & 52 & 1 & 55 & 1 & 56 \\
\hline & & $p=0.03$ & & $p=0.03$ & & NS \\
\hline
\end{tabular}

*Patients in whom the Ss infection was not evaluated were excluded

** $\mathbf{x}, \mathbf{y}, \mathbf{z}$ : Percentile $[25,50,75]$

Ss: Strongyloïdes stercoralis

The entrance in AIDS stage is defined by CD4-T count $<0.2 .10^{9} / \mathrm{L}$.

$\mathrm{N}$ : number of patients, NS: no significant, critical level: $\mathrm{p}<0.05$

Table 2b: Age of HIV patients at the moment of three irreversible events (HIV diagnosis, AIDS stage, death) in the four groups in AIDS patients (Univariate analysis).

\begin{tabular}{|c|c|c|c|c|}
\hline $\begin{array}{l}\text { Groups of } \\
\text { patients* }\end{array}$ & $\begin{array}{l}\text { Whole } \\
\text { cohort* }^{*} \\
\mathbf{N}\end{array}$ & $\begin{array}{c}\text { Age of maximal } \\
\text { amount eosinophils } \\
{[x, y, z]^{\star *}}\end{array}$ & $\underset{\mathrm{N}}{\text { AIDS patients }^{*}}$ & $\begin{array}{c}\text { Age of maximal } \\
\text { amount eosinophils } \\
{[x, y, z]^{\star *}}\end{array}$ \\
\hline HTLV- Ss- & 283 & {$[31,36,46]$} & 169 & {$[32,38,45]$} \\
\hline HTLV+ Ss- & 30 & {$[46,55,65]$} & 16 & {$[44,55,65]$} \\
\hline HTLV- Ss+ & 41 & {$[36,41,49]$} & 29 & {$[35,42,49]$} \\
\hline HTLV+Ss+ & 14 & {$[41, \mathbf{5 0}, 57]$} & 10 & {$[42,50,56]$} \\
\hline all & 368 & $p=0,001$ & 224 & $P=0,001$ \\
\hline
\end{tabular}

*Patients in whom the Ss infection was not evaluated were excluded

${ }^{* *} \mathrm{x}, \mathrm{y}, \mathrm{z}$ : Percentile $[25,50,75]$

Ss: Strongyloïdes stercoralis

The entrance in AIDS stage is defined by CD4-T count $<0.2 .10^{9} / \mathrm{L}$.

$\mathrm{N}$ : number of patients, critical level: $p<0.05$

Table 2c: Age of HIV patients at the moment of maximal amount of eosinophils in whole cohort* and AIDS patients.

\begin{tabular}{|c|c|c|c|c|c|c|c|}
\hline \multicolumn{2}{|l|}{ Event } & $\mathrm{N}$ & CD4 & $p$-value & $\mathrm{N}$ & CD8 median** & p-value \\
\hline \multirow[t]{2}{*}{ Eosinophilia* } & yes & 88 & 0.091 & \multirow[t]{2}{*}{0.0034} & 88 & 0.687 & \multirow[t]{2}{*}{ NS } \\
\hline & no & 309 & 0.187 & & 300 & 0.739 & \\
\hline \multirow[t]{2}{*}{ HTLV-1 } & yes & 46 & 0.241 & \multirow[t]{2}{*}{0.0049} & 44 & 0.783 & \multirow[t]{2}{*}{ NS } \\
\hline & no & 351 & 0.143 & & 344 & 0.727 & \\
\hline \multirow[t]{2}{*}{ Ss } & yes & 47 & 0.175 & \multirow[t]{2}{*}{$4.10^{-4}$} & 47 & 0.755 & \multirow[t]{2}{*}{ NS } \\
\hline & no & 279 & 0.108 & & 271 & 0.652 & \\
\hline
\end{tabular}

*yes: $>1.10^{9} / \mathrm{L}$, no: $<1.10 \% / \mathrm{L}$

${ }^{* *} \times 10 \%$

Ss: Strongyloïdes stercoralis

$\mathrm{N}$ : number of patients, NS: no significant

Table 3a: Comparison of CD4-T and CD8-T rates in terms of either eosinophilia $\left(\left(>1.10^{\%} / \mathrm{L}\right), \mathrm{HTLV}-1\right.$ infection or Ss infection in the whole cohort (Kruskal-Wallis test, critical level: $p<0.05$ )

\begin{tabular}{|c|c|c|c|c|c|c|c|}
\hline \multicolumn{2}{|l|}{ Event } & $\mathrm{N}$ & CD4 & $p$-value & $\mathrm{N}$ & CD8 median** & p-value \\
\hline \multirow[t]{2}{*}{ Eosinophilia* } & yes & 59 & 0.025 & \multirow[t]{2}{*}{ NS } & 59 & 0.566 & \multirow[t]{2}{*}{ NS } \\
\hline & no & 139 & 0.047 & & 132 & 0.531 & \\
\hline \multirow[t]{2}{*}{ HTLV-1 } & yes & 23 & 0.164 & \multirow[t]{2}{*}{ NS } & 21 & 0.423 & \multirow[t]{2}{*}{ NS } \\
\hline & no & 175 & 0.038 & & 170 & 0.536 & \\
\hline \multirow[t]{2}{*}{ Ss } & yes & 33 & 0.094 & \multirow[t]{2}{*}{ NS } & 33 & 0.653 & \multirow[t]{2}{*}{ NS } \\
\hline & no & 161 & 0.035 & & 154 & 0.521 & \\
\hline
\end{tabular}

*yes: $>1.10^{9} / \mathrm{L}$, no: $<1.10^{9} / \mathrm{L}$

** $\times 10^{9} / \mathrm{L}$

Ss: Strongyloïdes stercoralis

$\mathrm{N}$ : number of patients, NS: no significant

Table 3b: Comparison of CD4-T and CD8-T rates in terms of either eosinophilia $\left(>1.10^{\%} / \mathrm{L}\right), \mathrm{HTLV}-1$ infection or Ss infection in AIDS patients (Kruskal-Wallis test, critical level: $p<0.05$ )

\begin{tabular}{|c|c|c|c|c|c|c|c|}
\hline \multicolumn{2}{|l|}{ Event } & $\mathrm{N}$ & CD4 & $p$-value & $\mathrm{N}$ & CD8 median** & p-value \\
\hline \multirow[t]{2}{*}{ Eosinophilia* } & yes & 29 & 0.346 & \multirow[t]{2}{*}{ NS } & 29 & 0.976 & \multirow[t]{2}{*}{ NS } \\
\hline & no & 170 & 0.326 & & 168 & 0.931 & \\
\hline \multirow[t]{2}{*}{ HTLV-1 } & yes & 23 & 0.465 & \multirow[t]{2}{*}{ NS } & 23 & 1.061 & \multirow[t]{2}{*}{ NS } \\
\hline & no & 175 & 0.321 & & 174 & 0.931 & \\
\hline \multirow[t]{2}{*}{ Ss } & yes & 14 & 0.476 & \multirow[t]{2}{*}{ NS } & 14 & 1.033 & \multirow[t]{2}{*}{ NS } \\
\hline & no & 118 & 0.289 & & 117 & 0.88 & \\
\hline
\end{tabular}

*yes: > 1.10\%/L, no: < 1.10\%/L,

** $\times 10^{9} / \mathrm{L}$.

Ss: Strongyloïdes stercoralis

$\mathrm{N}$ : number of patients, NS: no significant

Table 3c: Comparison of CD4-T and CD8-T rates in terms of either eosinophilia (>1.10\%/L), HTLV-1 infection or Ss infection in

asymptomatic patients (Kruskal-Wallis test, critical level: $p<0.05$ ) 
Page 4 of 7

\begin{tabular}{|c|c|c|c|c|c|c|c|c|}
\hline \multicolumn{2}{|c|}{ Event } & $\mathrm{N}$ & $<0.2 \mathrm{CD}^{*} \%$ & $\mathrm{~N}$ & $0.2<C D 4<0.5^{*} \%$ & $\mathrm{~N}$ & $>0.5 \mathrm{CD} 4 * \%$ & p-value \\
\hline Eosinophilia** & yes & 60 & 68.2 & 15 & 17 & 13 & 14.8 & \multirow{2}{*}{0.01} \\
\hline & no & 165 & 53.4 & 84 & 27.2 & 60 & 19.4 & \\
\hline \multirow[t]{2}{*}{ HTLV-1 } & yes & 19 & 41.3 & 11 & 23.9 & 16 & 34.8 & \multirow[t]{2}{*}{0.02} \\
\hline & no & 190 & 58.7 & 88 & 25.1 & 57 & 16.2 & \\
\hline \multirow[t]{2}{*}{ Ss } & yes & 27 & 57.5 & 10 & 21.3 & 10 & 21.3 & \multirow[t]{2}{*}{ NS } \\
\hline & no & 183 & 64.9 & 60 & 21.5 & 38 & 13.6 & \\
\hline
\end{tabular}

$\mathrm{N}$ : number of patients, NS: no significant, critical level: $\mathrm{p}<0.05$

**yes: $>1.10^{\circ} / \mathrm{L}$, no: $<1.10^{\%} / \mathrm{L}$

Ss: Strongylö̈des stercoralis

Table 4: Comparison of proportions of patients with eosinophilia (>1.10\%/), HTLV-1 infection or Ss infection (Chi2 test) in each CD4 class*: either inferior to $0.2 .10^{\circ} / \mathrm{L}$, between $0.2 .10^{9} / \mathrm{L}$ and $0.5 .10^{\circ} / \mathrm{L}$ or superior to $0.5 .10^{\%} \mathrm{~L}$. CD4-T count $<0.2 .10^{\circ} / \mathrm{L}$ defines the entrance in AIDS stage.

\begin{tabular}{|c|c|c|c|c|c|c|c|c|c|}
\hline $\begin{array}{l}\text { Studied } \\
\text { variables }\end{array}$ & $\begin{array}{c}\text { Whole cohort } \\
\text { (N = 368) }\end{array}$ & \multicolumn{2}{|c|}{ Eos $>1.10^{\circ} / \mathrm{L}$} & \multicolumn{3}{|c|}{ Univariate analysis } & \multicolumn{2}{|c|}{ Multivariate analysis } \\
Final model
\end{tabular}

* Patients in whom the infection of Ss was not evaluated was excluded

OR: odds ratio, $\mathrm{Cl}$ : confidence interval

The $p$ value was calculated with the use of an adjusted Cox proportional hazards model

Ss: Strongyloïdes stercoralis, eos: eosinophils

$\mathrm{N}$ : number of patients, critical level: $\mathrm{p}<0.05$

Table 5: Coinfluence of HTLV-1 and Ss on eosinophils (Eos) in HIV patients (Logistic regression).

\section{Co-influence of HTLV1 and Ss on amount of eosinophils (logistic regression)}

With regard to eosinophils counts and eosinophilia $\left(>1.10^{9} / \mathrm{L}\right)$ prevalence, no significant difference was revealed when patients coinfected by HTLV-1 and Ss were compared to those only infected by Ss $(6 / 13$ versus $10 / 20, p=0.1)$. Otherwise the risk for eosinophilia was higher in male (Odds ratio of $2.26,95 \%$ confidence interval: $1.66 ; 6.25)$ and in patients infected by Ss (Odds ratio of $2.68,95 \%$ confidence interval: 1.47;4.91) (Table 5).

\section{Analysis of survival}

In asymptomatic patients the median survival time was not reached at study endpoint. The different variables studied i.e. Ss infection, HTLV1 infection and eosinophilia were not related to death in opposition to the AIDS stage. Indeed, the different actuarial curves of survival (data not shown) did not show any significant difference for these parameters. The Cox model analysis confirmed the analysis by the actuarial method and showed a 9.4 times higher relative risk to death in the AIDS stage as compared to the other patients. In the AIDS stage, analysis showed that others studied variables, sex, HTLV-1 or Ss infections, eosinophilia, were not related to death in studied population (Table 6).

\section{Discussion}

In HIV infection a moderate eosinophilic reaction is commonly observed without identifying a specific etiologic agent $[15,16]$. The increase of blood eosinophils as well as the augmentation of $\operatorname{IgE}$ accompanying often skin diseases are observed in the advanced stage of HIV infection and thus are considered of poor prognosis [17-19]. In opposition, the in vivo increased production of IL-4 and IgE as well as eosinophils increased amount noted in patients in the asymptomatic stage of HIV infection is in agreement with a protector effect of the IgE/eosinophil system [20,21]. Otherwise, activated eosinophils can generate a number of toxic substances (eosinophil peroxydase, hydrogen peroxide and holide ions) which have lytic effects on HIV [22]. On opposite, in vitro HIV-infected eosinophils do not survive and they die by apoptosis or necrosis [23]. However, these findings are not informative about eosinophils' impact on the progression of HIV infection.

In this study, we analyzed the protective or detrimental role of pathogens such as HTLV-1 and/or Ss on the progression of HIV infection through their potential function as inductor or modulator of the eosinophilic reaction. Our results suggest that the IgE/eosinophil system should operate differentially in function of the stage of the HIV infection. In the asymptomatic phase, the viral NSI/M-tropic strains use preferentially the CCKR5 receptor. RANTES, a strong chemoattractant for CD4/CD45RO T cells [24], secreted by eosinophils [2,7], should block the HIV-receptor CCK-R5 of adjacent CD4-T cells; by this way eosinophils (induced by Ss) should be a limiting factor for HIV infection. Otherwise, the observations of the decrease of RANTES in blood in "progressors as compared to "non-progressors on the one hand 
Page 5 of 7

\begin{tabular}{|c|c|c|c|c|c|c|c|c|c|}
\hline \multirow[t]{2}{*}{ Studied variables } & \multirow{2}{*}{$\begin{array}{l}\text { Whole cohort } \\
\text { (N = 445) }\end{array}$} & \multicolumn{2}{|c|}{ Death } & \multicolumn{3}{|c|}{ Univariate analysis } & \multicolumn{3}{|c|}{ Final model } \\
\hline & & $\mathbf{N}$ & $\%$ & $\begin{array}{c}\text { RR } \\
\text { crude }\end{array}$ & $95 \% \mathrm{Cl}$ & $p$-value & $\begin{array}{c}\text { RR } \\
\text { crude }\end{array}$ & $95 \% \mathrm{Cl}$ & p-value \\
\hline AIDS & & & & & & $<10^{-4}$ & & & $<10^{-4}$ \\
\hline No & 214 & 21 & 10 & 1,00 & & & 1,00 & & \\
\hline Yes & 231 & 160 & 69 & 9,42 & {$[5,97 ; 14,88]$} & & 9,42 & {$[5,97 ; 14,88]$} & \\
\hline Sex & & & & & & $<10^{-3}$ & & & \\
\hline Female & 135 & 47 & 35 & 1,00 & & & & & \\
\hline Male & 310 & 134 & 48 & 1,48 & {$[0,97 ; 2,26]$} & & & & \\
\hline Eosinophils $>1.10^{9} / \mathrm{L}$ & & & & & & 0.110 & & & \\
\hline No & 342 & 129 & 38 & 1,00 & & & & & \\
\hline Yes & 103 & 52 & 50 & 1,30 & {$[0,94 ; 1,79]$} & & & & \\
\hline HTLV & & & & & & 0.069 & & & \\
\hline No & 384 & 156 & 41 & 1,00 & & & & & \\
\hline Yes & 56 & 25 & 45 & 1,48 & {$[0,97 ; 2,26]$} & & & & \\
\hline Ss & & & & & & 0.09 & & & \\
\hline No & 313 & 144 & 46 & 1.00 & & & & & \\
\hline Yes & 55 & 30 & 55 & 1.41 & {$[0,95 ; 2.09]$} & & & & \\
\hline
\end{tabular}

RR: estimated Relative Risk, Cl: confidence interval. The RR are calculated at the end of the study (study endpoint march 30,1996$)$.

$\mathrm{N}$ : number of patients, Ss: Strongyloïdes stercoralis

Table 6: Results of the multivariate analysis of relative risk to death according to HTLV-1 and Ss infections, eosinophils count, AIDS phase and sex using Cox regression model ( $p$-value at $25 \%)$.

and the increase of RANTES in patients treated by protease inhibitor on the other hand also suggest a role for RANTES in the control of HIV infection [13].

So, in the asymptomatic phase of the disease, Ss infection inductor of stimulated eosinophils that produces RANTES would be unfavorable to HIV [22]. In the advanced AIDS disease, the period of the SI/T tropic viral strains whose preferential receptor is CXCR4, activated eosinophils sensitive to the HIV infection die and so they contribute to the progression of the disease $[23,25,26]$.

\section{HTLV-1 influence on eosinophils and CD4-T and CD8-T counts}

Influence of HTLV-1 on blood eosinophils amount: Our data indicate that HIV patients co-infected by HTLV-1 do not present significantly different values of circulating eosinophils as compared to patients infected only by HIV (table V). Otherwise, in opposition to skin diseases related to HIV [17-19], those observed in HTLV-1 infection in the course of the adult T-cell leukaemia/lymphoma (ATL) [27] or the infectious dermatitis related to HTLV-1 [28], do not show a cutaneous infiltration of eosinophils or blood eosinophilia. So, these data suggest that HTLV-1 does not modify eosinopoïesis. However, this proposal is in opposition to the others findings [29-31]. This difference could be explained, first by the means of the recruitment of the patients, second by the non considering of parasitic infections, in particular the helminthic infections and third by a too low threshold retained for the definition of eosinophilia.

Influence of HTLV-1 on CD4 and CD8 T-cells: Several studies have shown that in HTLV-1 coinfected HIV-patients the number of HTLV-1+CD4-T [32-35] or HTLV-1+CD8-T is increased [35,36]. In agreement with these studies, we demonstrate that carriers of both HIV and HTLV-1 present a significantly higher level of CD4-T lymphocytes as compared to patients infected only by HIV. A spontaneous activation and proliferation of lymphocytes in the presence of HTLV-1 may cause this finding [37], especially as co-infected by Ss [38]. On the other hand, in our study, HTLV-1 co-infection does not alter the amount of peripheral CD8-T cells under any conditions (Table $3 \mathrm{a}, \mathrm{b}, \mathrm{c}$ ).
Reactive ability of eosinophils in HIV patients co-infected with Ss and HTLV-1: Eosinophilia and an increased production of IgE (markers of a Th2 response) are common features of helminthic infections. In HIV-infected patients, preservation and even an expansion of the eosinophilic lineage are observed [19-21]. According to our study, the frequency of eosinophilia and its level in HIV patients coinfected by Ss or by both Ss and HTLV-1 are the same as those commonly observed in patients only infected by Ss or by both Ss and HTLV-1 and not by HIV, even when the levels of CD4-T and CD8-T are low. Thus it appears that neither HIV infection, nor HTLV-1 infection does affect the beneficial reactive ability of the eosinophils against helminthic parasites, in particular Ss. In line with this, in Martinique, which is an endemic area for HIV, HTLV-1 and Ss, HIV-infected patients in opposition to those infected only by HTLV-1 are less often infected by Ss and the hyperinfection syndrome of Ss is uncommon [39].

Independence of the eosinophilogenic CD4-T and CD8-T populations: Eosinophilia detected in HIV-infected patients, in particular in those co-infected by Ss, gives evidence that either CD4-T clones or the cytokines controlling the eosinopoïesis are not affected by the HIV infection or that this function is assured by CD4-CD8+ T clones. Several reports are in agreement with this hypothesis insofar as CD8-T-lymphocytes would mime a Th2 function in producing IL-4, IL-5 $[40,41]$. The degeneration of the cellular immunity relative to the CD4/CD8/Cytotoxic-T lymphocyte effector system would slow down and would partially be compensated by the amplification of the CD8-T dependent eosinophil/IgE effector system [42]. Actually our results do not reveal any correlation as concerns the level of CD4-T, CD8-T cells and eosinophilia. In particular, when the level of CD4-T cells is inferior to $0.2 .10^{9} / \mu \mathrm{L}, \mathrm{CD} 8$ - T cells no more decrease and eosinophilia is independent of level of CD4-T and CD8-T cells; except for the whole cohort no eosinophilia was significantly associated with a higher level of CD4-T cells (table 3a).

Impact of eosinophilia on clinical progression in HTLV-1 co-infected HIV patients: Evidence of eosinophilia and increased serum levels of IgE observed in the advanced clinical phase of HIV infection suggest that these biological parameters can be considered of poor prognosis [17-19]. Several studies have shown that in HTLV- 
1 coinfected HIV-patients the clinical progression of the disease is accelerated when compared to patients only infected by HIV [32,4345]. However other studies have not confirmed the observation that HTLV-1 modulates the clinical progression in HIV infected patients $[46,47]$. Our study reveals in dually HIV/HTLV-1 infected patients the same level of eosinophils as compared to patients only infected by HIV (table 5). Hence, during the AIDS phase in dually infected HIV/ HTLV-1 patients, the progression of the disease should be equivalent. Nevertheless this hypothesis is in opposition to several studies [44-46]. Otherwise, the relative resistance to HIV of patients belonging to a risk group (multiple high-risk sexual exposures) unfortunately does not give any indication neither of their parasitic and retroviral co-infections nor on their level of eosinophils in peripheral blood [1].

Whatever the reason of eosinophilia, in our study HIV patients with eosinophilia and HIV patients either co-infected by HTLV-1 or by both HTLV-1 and Ss presented a median age superior to the one of patients only infected by HIV (Table 2 a,b,c). This observation which is consistent with other reports $[39,46]$ implies a slower progression in HTLV-1/Ss co-infected patients to AIDS disease and hence are later diagnosed. The beneficial eosinophilia, induced by chronic helminthic infections such as Ss or others helminths, elaborating an excess of chemokines such as RANTES, IL-16 and MIP-1 $1 \alpha$ partakes perhaps to the observed protection or at least to the delayed AIDS disease $[39,48,49]$.

Nevertheless analysis of the global survival, survival curves ( data not shown) and associated risk of the explanatory parameters after the AIDS phase do not show any significant difference in AIDS patients coinfected by HTLV-1 and/or Ss and non-co-infected patients (Table 6) : the length of AIDS stage were not modified by Ss/HTLV-1 coinfections

HIV and HTLV-1 infections alter the IL-2/IL-2R system. So, HIV infected patients exhibit a failure in producing IL-2 and its receptor $[20,50]$. At the contrary, HTLV-1 infection induces in asymptomatic carriers a variable expression of IL-2 (Th1 profile) and its receptor [51,52]. Furthermore, a prolonged administration of small quantities of IL-2 in HIV patients induces the expansion of NK effector cells and of eosinophils without causing first any toxicity, second an enhancement of the viral charge and third an appearance of opportunistic infections in a follow-up of fifty months [53]. So, the HTLV-1 by inducing a low IL-2 expression and restoring the NK activity in the asymptomatic stage of HIV infection would arrest the progression to the AIDS disease. In vivo HTLV-1 by means of hampering the Th2 profile [54] would induce a decrease of eosinophil activation and hence would limit their HIV infection.

\section{Conclusion}

Our study suggests that eosinophils exert different functions according to HIV infection phase: protective during the asymptomatic phase, harmful during AIDS phase. Overall survival of HIV patients co-infected by HTLV-1 or Ss is lengthier than the one of patients only infected by HIV. Our study suggests a lengthening of the asymptomatic phase; however, co-infections by Ss or HTLV-1 do not modify the survival time of AIDS phase. Otherwise, our observations reveal the problem of the control of retroviral and helminthic co-infections which disturb the complex and fragile balance of the cytokines and their receptors expressed on lymphocytes and eosinophils. Eosinophils in elaborating cytokines either of type Th1 or type Th2 participate to the general control of the response of T cells [55-57]. So, they could modulate the evolution of HIV infection, especially in the asymptomatic stage.

\section{References}

1. Paxton WA, Martin SR, Tse D, O'Brien TR, Skurnick J, et al. (1996) Relative resistance to HIV-1 infection of CD4 lymphocytes from persons who remain uninfected despite multiple high-risk sexual exposure.Nat Med 2: 412-417.

2. Dragic T, Litwin V, Allaway GP, Martin SR, Huang Y, et al. (1996) HIV-1 entry into CD4+ cells is mediated by the chemokine receptor CC-CKR-5.Nature 381: 667-673.

3. Baier M, Werner A, Bannert N, Metzner K, Kurth R (1995) HIV suppression by interleukin-16.Nature 378: 563.

4. Cocchi F, DeVico AL, Garzino-Demo A, Arya SK, Gallo RC, et al. (1995) Identification of RANTES, MIP-1 alpha, and MIP-1 beta as the major HIVsuppressive factors produced by CD8+ T cells.Science 270: 1811-1815.

5. Chihara J, Oyamada H, Yamada H, Tsuda A, Kamada Y, et al. (1997) Expression of mRNA for RANTES in human eosinophils.Int Arch Allergy Immunol 114 Suppl 1: 33-35.

6. Lim KG, Wan HC, Bozza PT, Resnick MB, Wong DT, et al. (1996) Human eosinophils elaborate the lymphocyte chemoattractants. IL-16 (lymphocyte chemoattractant factor) and RANTES.J Immunol 156: 2566-2570.

7. Ying S, Meng Q, Taborda-Barata L, Corrigan CJ, Barkans J, et al. (1996) Human eosinophils express messenger RNA encoding RANTES and store and release biologically active RANTES protein.Eur J Immunol 26: 70-76.

8. Plumelle Y (2003) HIV, 'an evolving species'. Roles of cellular activation and co-infections.Med Hypotheses 61: 136-157.

9. Salahuddin SZ, Markham PD, Lindner SG, Gootenberg J, Popovic M, et al. (1984) Lymphokine production by cultured human T cells transformed by human T-cell leukemia-lymphoma virus-I.Science 223: 703-707.

10. Li-Weber M, Giaisi M, Chlichlia K, Khazaie K, Krammer PH (2001) Human T cell leukemia virus type I Tax enhances IL-4 gene expression in T cells.Eur J Immunol 31: 2623-2632.

11. Sato Y, Shiroma Y (1989) Peripheral lymphocyte subsets and their responsiveness in human strongyloidiasis.Clin Immunol Immunopathol 53: 430-438.

12. Enokihara H, Furusawa S, Nakakubo H, Kajitani H, Nagashima S, et al. (1989) $\mathrm{T}$ cells from eosinophilic patients produce interleukin-5 with interleukin-2 stimulation.Blood 73: 1809-1813.

13. Aukrust $P$, Müller F, Frøland SS (1998) Circulating levels of RANTES in human immunodeficiency virus type 1 infection: effect of potent antiretroviral therapy.J Infect Dis 177: 1091-1096.

14. De Luca A, Giancola MI, Cingolani A, Ammassari A, Murri R, Antimori A (2000) Circulating levels and ex vivo production of beta-chemokines, interferon gamma and interleukin 2 in advanced human immunodeficiency virus type 1 infection: the effect of protease inhibitor therapy. AIDS Res Hum Retroviruses 16: $1835-1843$.

15. Sanchez-Borges M, Orozco A, Di Biagio E, Tami I, Suarez-Chacon R (1993) Eosinophilia in early-stage human immunodeficiency virus infection.J Allergy Clin Immunol 92: 494-495.

16. Tietz A, Sponagel L, Erb P, Bucher H, Battegay M, et al. (1997) Eosinophilia in patients infected with the human immunodeficiency virus.Eur $\mathrm{J}$ Clin Microbiol Infect Dis 16: 675-677.

17. Skiest DJ, Keiser P (1997) Clinical significance of eosinophilia in HIV-infected individuals.Am J Med 102: 449-453.

18. Israël-Biet D, Labrousse F, Tourani JM, Sors H, Andrieu JM, et al. (1992) Elevation of IgE in HIV-infected subjects: a marker of poor prognosis.J Allergy Clin Immunol 89: 68-75.

19. Basarab T, Russell Jones R (1996) HIV-associated eosinophilic folliculitis: case report and review of the literature. Br J Dermatol 134: 499-503.

20. Clerici M, Hakim FT, Venzon DJ, Blatt S, Hendrix CW, et al. (1993) Changes in interleukin-2 and interleukin-4 production in asymptomatic, human immunodeficiency virus-seropositive individuals.J Clin Invest 91: 759-765.

21. Cohen AJ, Steigbigel RT (1996) Eosinophilia in patients infected with human immunodeficiency virus.J Infect Dis 174: 615-618.

22. Klebanoff SJ, Coombs RW (1996) Virucidal effect of stimulated eosinophils on human immunodeficiency virus type 1.AIDS Res Hum Retroviruses 12: 25-29. 
23. Weller PF, Marshall WL, Lucey DR, Rand TH, Dvorak AM, et al. (1995) Infection, apoptosis, and killing of mature human eosinophils by human immunodeficiency virus-1.Am J Respir Cell Mol Biol 13: 610-620.

24. Schall TJ, Bacon K, Toy KJ, Goeddel DV (1990) Selective attraction of monocytes and T lymphocytes of the memory phenotype by cytokine RANTES. Nature 347: 669-671.

25. Wooley Dp, Peterson Kt, Taylor Rj, Paul Cc, Baumann Ma (2000) Straindependent productive infection of a unique eosinophilic cell line by human immunodeficiency virus type 1. AIDS Res Hum Retroviruses 16: 1405-1415.

26. Taylor RJ, Schols D, Wooley DP (2004) Restricted entry of R5 HIV Type 1 strains into eosinophilic cells.AIDS Res Hum Retroviruses 20: 1244-1253.

27. Bunn PA Jr, Schechter GP, Jaffe E, Blayney D, Young RC, et al. (1983) Clinical course of retrovirus-associated adult T-cell lymphoma in the United States.N Engl J Med 309: 257-264.

28. LaGrenade L, Hanchard B, Fletcher V, Cranston B, Blattner W (1990) Infective dermatitis of Jamaican children: a marker for HTLV-I infection.Lancet 336: 1345-1347.

29. Welles SL, Mueller N, Tachibana N, Shishime E, Okayama A, et al. (1991) Decreased eosinophil numbers in HTLV-I carriers. Lancet 337: 987.

30. Prin L, Leguern M, Ameisen JC, Saragosti S, Bletry O, et al. (1988) HTLV-I and malignant hypereosinophilic syndrome.Lancet 2: 569-570.

31. Chavance M, Monplaisir N, Schaffar-Deshayes L, Valette I, Fréry N (1988) Eosinophil count in healthy HTLV-I carriers.Lancet 2: 1309.

32. Schechter M, Moulton LH, Harrison LH (1997) HIV viral load and CD4+ lymphocyte counts in subjects coinfected with HTLV-I and HIV-1.J Acquir Immune Defic Syndr Hum Retrovirol 15: 308-311.

33. Fantry L, De Jonge E, Auwaerter PG, Lederman HM (1995) Immunodeficiency and elevated CD4 T lymphocyte counts in two patients coinfected with human immunodeficiency virus and human lymphotropic virus type I.Clin Infect Dis 21: 1466-1468.

34. Wiley CA, Nerenberg M, Cros D, Soto-Aguilar MC (1989) HTLV-I polymyositis in a patient also infected with the human immunodeficiency virus.N Engl J Med 320: 992-995.

35. Ehrlich GD, Davey FR, Kirshner JJ, Sninsky JJ, Kwok S, et al. (1989) A polyclonal $\mathrm{CD} 4+$ and $\mathrm{CD} 8+$ lymphocytosis in a patient doubly infected with HTLV-I and HIV-1: a clinical and molecular analysis.Am J Hematol 30: 128-139.

36. Bessinger R, Beilke M, Kissinger P, Jarrott C, Tabak OF (1997) Retroviral coinfections at a New Orleans HIV outpatient clinic.J Acquir Immune Defic Syndr Hum Retrovirol 14: 67-71.

37. Cavrois M, Gessain A, Wain-Hobson S, Wattel E (1996) Proliferation of HTLV-1 infected circulating cells in vivo in all asymptomatic carriers and patients with TSP/HAM.Oncogene 12: 2419-2423.

38. Satoh M, Toma H, Sugahara K, Etoh K, Shiroma Y, et al. (2002) Involvement of IL-2/IL-2R system activation by parasite antigen in polyclonal expansion of CD4(+)25(+) HTLV-1-infected T-cells in human carriers of both HTLV-1 and S. stercoralis. Oncogene 21: 2466-2475.

39. Plumelle Y, Edouard A (1996) [Strongyloides stercoralis in T-cell leukemia/ lymphoma in adults and acquired immunodeficiency syndrome].Rev Med Interne 17: 125-129.

40. Maggi E, Giudizi MG, Biagiotti R, Annunziato F, Manetti R, et al. (1994) Th2like CD8+ T cells showing $B$ cell helper function and reduced cytolytic activity in human immunodeficiency virus type 1 infection.J Exp Med 180: 489-495.

41. Paganelli R, Scala E, Ansotegui IJ, Ausiello CM, Halapi E, et al. (1995) CD8+ T lymphocytes provide helper activity for IgE synthesis in human immunodeficiency virus-infected patients with hyper-lgE.J Exp Med 181: 423428.

42. Grossman Z, Herberman RB (1997) T-cell homeostasis in HIV infection is neither failing nor blind: modified cell counts reflect an adaptive response of the host.Nat Med 3: 486-490.
43. Beilke MA, Japa S, Vinson DG (1998) HTLV-I and HTLV-II virus expression increase with HIV-1 coinfection.J Acquir Immune Defic Syndr Hum Retrovirol 17: 391-397.

44. Gotuzzo E, Escamilla J, Phillips IA, Sánchez J, Wignall FS, et al. (1992) The impact of human T-lymphotrophic virus type $\mathrm{I} / \mathrm{ll}$ infection on the prognosis of sexually acquired cases of acquired immunodeficiency syndrome.Arch Intern Med 152: 1429-1432.

45. Bartholomew C, Blattner W, Cleghorn F (1987) Progression to AIDS in homosexual men co-infected with HIV and HTLV-I in Trinidad.Lancet 2: 1469.

46. Chavance M, Neisson-Vernant C, Quist D, Monplaisir N, Armengaud B, et al. (1995) HIV/HTLV-I coinfection and clinical grade at diagnosis.J Acquir Immune Defic Syndr Hum Retrovirol 8: 91-95.

47. Harrison LH, Quinn TC, Schechter M (1997) Human T cell lymphotropic virus type I does not increase human immunodeficiency virus viral load in vivo.J Infect Dis 175: 438-440.

48. Elliott AM, Mawa PA, Joseph S, Namujju PB, Kizza M, et al. (2003) Associations between helminth infection and $\mathrm{CD} 4+\mathrm{T}$ cell count, viral load and cytokine responses in HIV-1-infected Ugandan adults. Trans R Soc Trop Med Hyg 97: 103-108.

49. Brown M, Kizza M, Watera C, Quigley MA, Rowland S, et al. (2004) Helminth infection is not associated with faster progression of HIV disease in coinfected adults in Uganda.J Infect Dis 190: 1869-1879.

50. David D, Bani L, Moreau JL, Treilhou MP, Nakarai T, et al. (1998) Regulatory dysfunction of the interleukin-2 receptor during HIV infection and the impact of triple combination therapy.Proc Natl Acad Sci U S A 95: 11348-11353.

51. Tanaka Y, Oda S, Nagata K, Mori N, Sakamoto H, et al. (1989) Immunological functions and phenotypes of peripheral blood lymphocytes from human T-cell leukemia virus-I carriers.J Clin Immunol 9: 477-484.

52. Prince HE, Jackson AL (1990) Normal expression of p55 interleukin 2 receptor (CD25) by lymphocytes from former blood donors seropositive for human $T$ lymphotropic virus.Clin Immunol Immunopathol 57: 459-464.

53. Bernstein ZP, Porter MM, Gould M, Lipman B, Bluman EM, et al. (1995) Prolonged administration of low-dose interleukin-2 in HIV-associated malignancy results in selective expansion of innate immune effectors without significant clinical toxicity. Blood 86: 3287-3294.

54. Porto AF, Neva FA, Bittencourt H, Lisboa W, Thompson R, et al. (2001) HTLV1 decreases Th2 type of immune response in patients with strongyloidiasis. Parasite Immunol 23: 503-507.

55. Grewe M, Czech W, Morita A, Werfel T, Klammer M, et al. (1998) Human eosinophils produce biologically active IL-12: implications for control of T cell responses.J Immunol 161: 415-420.

56. Capron M, Desreumaux P, Gouni AS, Lamkhioued B, Capron A (1994) [Eosinophil, beneficial or harmful: a cell entirely part of immune response].C $R$ Seances Soc Biol Fil 188: 39-46.

57. Weller PF (1991) The immunobiology of eosinophils.N Engl J Med 324: 11101118. 